\title{
Challenges of Internationally Educated Teachers in the U.S. Public School System
}

\author{
JeeHae Helen Lee ${ }^{1}$ \\ ${ }^{1}$ College of Education, Troy University, Dothan, Alabama, USA \\ Correspondence: College of Education, Troy University, Dothan, Alabama, USA. Tel: 1-334-983-6556 (Ext. \\ 1354). E-mail: jhlee@troy.edu
}

Received: October 28, 2014 Accepted: November 28, 2014 Online Published: February 25, 2015

doi:10.5539/ies.v8n3p44

URL: http://dx.doi.org/10.5539/ies.v8n3p44

\begin{abstract}
A phenomenological research study was conducted to discover some of the challenges that internationally educated teachers face in the U.S. public school system. Interviews, in conjunction withbridling journal entries, were conducted with three internationally educated teachers who had experience teaching in the U.S. public school system, and whole-part-whole analysis was used to examine the interview scripts in the context of culture and language. The conceptual framework for this study was based on Bakhtin's authoritative discourses and his theory of language. The findings of this study revealed three broad challenges: hardships in classroom discipline due to cultural differences, conflicts with parents due to the lack of understanding of the U.S. mainstream culture, and language barriers. In addition, the implications for internationally educated teachers in the U.S. schools were discussed. Among the discussions, the implications for schools highlighted the need for a mutually respectful mentoring for the internationally educated teachers.
\end{abstract}

Keywords: internationally educated teachers, multicultural teachers, immigrant teachers, multilingual teachers

\section{Introduction}

\subsection{Introduction to Problem}

Since mid-1990s, the number of English Language Learners [ELLs] in the U.S. schools has increased to 5.2 million (National Clearinghouse for English Language Acquisition, 2011). As the ELL population has increased, issues related to ELL students have increased as well (e.g., language barriers, cultural shock, failures at school, increasing dropout rate, etc.) Unfortunately, however, many teachers do not have the required competence and skills to meet the needs of these students (Evans, Arnot-Hopffer, \& Jurich, 2005; Ladson-Billings, 2000; Rushton, 2000; Webster \& Valeo, 2011).

In order to better serve students with diverse cultural and linguistic backgrounds, some scholars have suggested hiring teachers with backgrounds similar to those of the students they teach (Ryan, Pollock, \& Antonelli, 2009). There are several arguments supporting this strategy. First, internationally educated teachers can serve as role models, mentors, and advocates (Clewell \& Villegas, 2001; Ladson-Billings, 1995; Milner, 2003, Oloo, 2012). Second, these teachers would have a better understanding of the needs of diverse students (Ragnarsdóttir, 2010). Third, internationally educated teachers would bring a unique perspective to the classroom due to their personal experiences with diversity-related issues (Quiocho \& Rios, 2000). Finally, internationally educated teachers could help bridge the differences between cultures by serving as "cultural translators" (Irvine, 1990, p. 51).

In spite of the rising need for teachers from culturally and linguistically diverse backgrounds, teachers in the U.S. are not as ethnically, culturally, linguistically and religiously diverse as the student groups they teach (Ladson-Billings, 1995, 2001; Lumby \& Coleman, 2007; Ragnarsdóttir, 2010). In addition, there are few studies examining the challenges that internationally educated teachers face (Gordon, 2000; Hwang, Baek, \& Vrongistinos, 2005; Omi \& Winant, 1994; Subedi, 2008), which may contribute to prejudice and discrimination against internationally educated teachers. Understanding the challenges of internationally educated teachers is a critical issue because it can help advance educational reforms, thus improving the educational experience of all students and teachers (Abramova, 2012; Ball \& Tyson, 2011).

\subsection{Purpose of Study}

The purpose of this study is to discover some of the challenges that internationally educated teachers face in the 
U.S. public school system by interviewing three internationally educated teachers who had experience teaching in the U. S. public school system.

\subsection{Conceptual Framework}

The conceptual framework for this study is based on Bakhtin's (1998) authoritative discourses and his theory of language. Bakhtin's (1981) two theories provided the framework for examining the experiences of internationally educated teachers from several different perspectives. Through the use of authoritative discourses, which are dominant discourses present in a social setting, this researcher examined how the participants were placed in a subordinate position in the U.S. schools where it is believed that an aristocratic, mainstream culture still dominates (Hodge, 2005).

Bakhtin's theory of language was used to explore language as a dynamic meaning-making process by which the identities of internationally educated teachers could be constructed and reconstructed. Bakhtin's theory was also used to examine how the language of internationally influences the creation and recreation of self-identity in terms of competence at work.

\section{Method}

A phenomenological approach was used to investigate the perceived challenges that internationally educated teachers experienced while teaching in the U.S. public schools. The phenomenological approach was used because of the emphasis placed on intentionality, consciousness, and the first-person perspective (K. Dahlberg, H. Dahlberg, \& Nystrom, 2008).

\subsection{Participants}

Three internationally educated teachers were selected from a range of public schools from urban settings in the southeastern part of the United States. The three teachers who participated in this study came from different schools and were already known to the researcher. All three participants moved to the United States as adults, spoke English as a foreign language, and received formal education from grades K-12 in their home countries. The teachers were from Europe, Colombia and Singapore. The researcher did not specify one participant's country of origin in order to protect the anonymity of the participant, and pseudonyms were used for all three participants. Their length of teaching in the U.S. public schools ranged from 4 to 19 years. At the time of the study, the participants were teaching in elementary schools as certified teachers in the U.S. public school system.

\subsection{Data Collection}

The data were gathered through semi-structured interviews and bridling journal entries.

\subsubsection{Interviews}

Using semi-structured interviews, the participants were asked to discuss why they chose to teach in the United States and what specific challenges they faced as internationally educated teachers. Each participant was interviewed for approximately two on five separate occasions, for a total to ten hours per participant. Five interviews were conducted for each participant. Follow-up interviews were conducted via e-mails and phone calls because the participants were traveling out of country. The number of follow-up interviews varied depending on the participant. Five follow-up interviews were conducted via e-mails with Annabel, six follow-up interviews were conducted via e-mails and phone calls with Niang, and four follow-up interviews were conducted via e-mails with Mares.

\subsubsection{Bridling Journal Entries}

Phenomenological researchers such as K. Dahlberg, H. Dahlberg, and Nystrom (2008) suggested bridling as a necessary part of a phenomenological study. Bridling is the process by which a researcher takes an open stance, scrutinizes his or her involvement with the phenomenon, and continually reflects upon how meanings "come to be" (p. 16) during the research. Bridling helped this researcher remain open to the phenomenon of investigation by actively practicing openness and humility throughout the data collection and data analysis. In an effort to constantly question the prejudices that the researcher might bring into this study, and also to develop an understanding of the phenomenon of the study, bridling journal entries were used during the data collection and data analysis. During the initial phase of the bridling journal entry, this researcher wrote an initial bridling statement in mid-January, 2010, before the data collection began in March, 2010. In this statement, the researcher wrote as much as she could about the challenges faced by internationally educated teachers and how they might meet their challenges. A bridling journal entry was written and dated after each data collection event. The new entries were compared to and contrasted with the initial bridling statement that was written in January, 2010. By doing so, the researcher was able to see the differences and similarities between the documents and 
question her assumptions and initial conclusions about the phenomenon.

\subsection{Data Analysis}

The whole-part-whole analysis approach advocated by K. Dahlberg, H. Dahlberg, and Nystrom (2008), Vagle (2010) and Van Manen (1990) was employed to analyze the data. This data analysis consisted of three steps. The first step, Reading of the Whole Data, involved highlighting statements, phrases and brief descriptions of the researcher's notes. The second step, Reading Part of the Data, involved articulating the meanings based on the highlighted statements and follow-up interviews. The third step, Reading of the Whole Data, explored patterns and coding in relation to the whole picture of the data.

\section{Results}

In this section aspects of the internationally educated teachers' sociocultural challenges are discussed. The challenges with regard to the internationally educated teachers' experiences resulted from three sources: hardships in classroom discipline due to cultural differences, conflicts with parents due to the lack of understanding of the U.S. mainstream culture, and language barriers. These three challenges are discussed through the lens of Bakhtin's authoritative discourses and his theory of language.

\subsection{Hardships in Classroom Discipline due to Cultural Differences}

This study defines cultural differences as differences in beliefs, attitudes and practices between the United States and the non-native teachers' home countries. The participants in this study experienced challenges, in part, because of the differences in educational beliefs and practices of the host school systems and the teachers' home countries. Despite the differences in culture, these internationally educated teachers were expected to accept the differences and deal with them professionally. Authoritative discourses (Bakhtin, 1998) at school can place teachers from outside the mainstream culture in a subordinate position and expect them to understand and to comply with the norms of the dominant culture. When these norms of the authoritative discourses conflicted with the norms of their home countries, the internationally educated teachers experienced cultural dissonance and confusion. However, if they complied with the norms of the authoritative discourses at school in the host country, they were perceived as professional and experienced less conflict at school. The findings related to cultural differences are discussed in terms of their impact on classroom discipline and conflicts with parents.

The three participants struggled in the beginning of their teaching careers, first, because they experienced a different level of respect from students in the United States as compared to students in their home countries and, second, because they were expected to understand and accept such difference in the host country. All three participants were raised in cultures where the teaching and learning environments emphasized respect for a teacher's authority. They struggled, in part, in the beginning of their teaching careers because they perceived the behaviors of the U.S. students as disrespectful. Annabel illustrated students' behaviors in her home country as follows:

When teachers enter[ed] the classroom [in my home country], every child had to stand up. That's how class was introduced. And then ...the teacher allowed us to sit down and started the lesson. The entire time we had our hands crossed behind [us]. There was no talking. [Although]... the number of students was ...probably, [from] 1st to 12 th grade, about ...30 to 33 students in one classroom with one teacher, we $\mathrm{d}[\mathrm{id}]$ not have [any behavior problem] at all.

On the contrary, Annabel described her students' behaviors in the U.S. schools during her first year teaching as follows:

When I entered the classroom, I was in shock how children were rude, disrespectful, wild, not listening, not following the classroom rules. I cried after I left [the classroom] and said [to myself that] I would never teach again. I think that was the hardest job that I ever had in my life. Most challenging!

Annabel's struggle came from the different level of respect demonstrated by students in her home country and in the United States. She described her students in Eastern Europe as respectful, while she considered her students in the United States as disrespectful.

Similarly, Mares explained how well her students behaved when she was a teacher in Colombia:

When [I] c[a]me in the classroom in my country, they st[oo]d up and they sa[id], "Good morning" or "Good afternoon." And then they s[a]t down. And then [I] start[ed] the classroom. Everybody listen[ed]. Actually there [wa]s no behavior problem.

However, her description of one of her students in the U.S. was quite contrary: 
[One boy] kicked on [the speech therapist's] breast. And then he got a stick, a metal stick that was on the floor, and hit her. When she came out, she was shaking. She was crying. She said, "This child has no respect for me, for anybody...I cannot work with him". And she left the classroom.

These two contrasting excerpts from Mares' interviews indicate that teaching in the U.S. schools seems to be more challenging than teaching in Columbia due to the lack of respect from the U. S. students.

The cultural differences between internationally educated teachers and students can lead to challenges in classroom discipline, which is one of the commonly observed challenges among internationally educated teachers during the initial phase of their teaching career in a host country (Oriaro, 2007; Ross, 2003; Su, 1997). The authoritative discourses in the U.S. schools expect internationally educated teachers to encourage students to freely express themselves while simultaneously maintaining classroom discipline. It is difficult for these teachers to meet such expectations early in their teaching careers in the host country because they rely on their home countries' educational practices and expectations on students' behaviors in this phase. According to Smyth and Kum (2010), overcoming such challenges requires internationally educated teachers to commit themselves in "re-education, re-orientation and re-skilling" (p. 512). As a result, the internationally educated teachers experience "a sense of cultural dissonance and a struggle to come to terms with the cultural worlds they knew" (Bascia, 1996, p. 7).

\subsection{Conflicts with Parents due to the Lack of Understanding of the U.S. Mainstream Culture}

One of the internationally educated teachers in this study had more conflicts with parents than the other two participants. Those two internationally educated teachers who understood and accepted the appropriate communication skills with parents in the U.S. schools quickly established rapport with them. However, the participant who did not understand appropriate communication skills and relied on her communication skills that she obtained from her home country, faced more conflicts with parents and was perceived as incompetent by her school administrator. Although not all of the internationally educated teachers in this study experienced this kind of challenge, it is important to mention it here because this shows how understanding and complying with the authoritative discourses (Bakhtin, 1998) at school in the host country provides internationally educated teachers with acceptance to the community and how the failure to understand and comply with the norms of the authoritative discourses at school denies them such reception. For example, coming from Colombia, where teachers could openly discuss and express their thoughts about almost all issues regarding their children, Mares unintentionally made some American parents upset when she attempted to frankly share her thoughts with those parents.

In our country, you can say, 'oh, you are lying' or 'you are a liar'...if the person is lying. I didn't know that you couldn't say that or refer to somebody like that in this country. I had a big problem [with parents at school]. I had a child who went home and talked to [his] parent something that we [did] to him. And the parent called [me] very upset. And when [she] told me what [her child] had said to her, I said, "I'm sorry but he is lying". [The parent] hung up on me and ... ten seconds after that, she came in[to] a classroom and said, "You do not call my son a liar!" She put her finger like that on my face. And I said, "Don't you ever put your finger next to my face!” And I went to talk to my principal. I don't think this is right. I don't think it's okay for her to come in[to] my classroom, screaming at me in front of [my] student[s]... And my principal said, "Oh, Mares, you can't call anybody a liar to start". So I said, "I think she needs to give me an apology." And [the principal] said, "No, who needs to give an apology to the parent is you." And I said, "Are you kidding me?" And I had to do it! It was that or I just had to go, you know. So that has been very difficult for me in this country to learn how ...not [to] get in trouble [with parents].

This event illustrates Mares's struggle due to her lack of understanding of the authoritative discourses in terms of communication with a parent (e.g., what was acceptable or unacceptable to say to a parent about her or his child). During the interviews, Mares said that she was often reprimanded by her school principal for her lack of communication skills. When Mares tried to use her previous Colombian communication skills with parents, her school principal reacted negatively. The authoritative discourses (Bakhtin, 1998) at school place internationally educated teachers in a subordinate position and pressure them to comply with the norms of the dominant culture. When internationally educated teachers fail to comply, they are perceived to be incompetent and are not welcomed in the community. In this case, Mares' failure to understand and follow the norms of the authoritative discourses at her school, such as what to say and what not to say to a parent about his or her child, resulted in her offending the parent and getting reprimanded by her school principal.

However, unlike Mares, both Annabel and Niang did not experience such conflicts with parents. A possible reason seemed to be the fact that both Annabel and Niang had learned how to interact and communicate with 
students' parents in U.S. public schools prior to their first teaching experience. Annabel experienced student teaching, substitute teaching and paraprofessional teaching before she became a certified teacher. Niang completed her student teaching in two different public schools. In addition, being a mother of four children who attend a U.S. public school helped increase Niang's understanding of the U.S. culture. These prior exposures to teaching and learning experiences gave both Annabel and Niang a better understanding of appropriate communication skills with the U.S. parents. Annabel mentioned that she learned how to interact with students' parents by watching and listening how her cooperating classroom teacher talked to her students' parents while she, Annaeble, was serving as a paraprofessional:

I had a chance to observe...the relationship between teachers and parents. [I] gain[ed] something from the teacher that [made me] stronger. And it also [gave me an] idea about how to solve certain problems. [I] gain[ed] the problem solving skills.

It appears that Annabel's experience as a paraprofessional before she became an ESOL teacher, provided her with a deeper understanding of how to communicate and interact with parents in the U.S. schools.

Similarly, Niang reported that being a mother of four children who were students in the U.S. public school system helped her communicate better with her students' parents because, being a parent of students in public schools, she understood what parents in the United States go through. "Because I have child[ren], I can relate to their feelings as parents." Niang's experiences as a mother seems to help her gain an appreciation for what the American parents go through and helped her establish a successful teacher-parent relationship.

Interestingly, both Annabel and Niang were married to U.S. citizens, but Mares was not. Her husband was Colombian. By marrying U.S. citizens, both Annabel and Niang obtained cultural capital (Bourdieu, 1986): U.S. citizenship, knowledge of mainstream culture, immediate acceptance to the mainstream U.S. culture, etc.

The importance of receiving support from spouses who are from the mainstream culture of the host country was also discussed by Ragnarsdóttir (2010) in her study of internationally educated teachers and student teachers in Iceland. The following excerpts from Annabel also echoed Ragnarsdóttir's finding. Annabel mentioned in the following excerpt about how her husband who is U.S. citizen supported her:

It was my husband who really helped me with challenges of English language...I communicate with him in English [everyday]. He always explained to me certain vocabulary word if I didn't understand...It would [have] be[en] very difficult for me [without my husband's support] to really get used to this...culture and language, to assimilate to the mainstream culture...

The above excerpt advances this researcher's argument that internationally educated teachers who are exposed to the U.S. mainstream culture prior to teaching in the U.S.(e.g. through paraprofessional teaching experiences, raising children in U.S. public schools or obtaining cultural capital through marriage to U.S. citizens), are better able to communicate and interact with the students and their parents. Looking at this argument in terms of Bakhtin's (1998) authoritative discourses, the internationally educated teachers' ability to understand and follow the norms of the authoritative discourses at their school (e.g., how to effectively communicate and establish rapport with parents) played a vital role in gaining acceptance in the school community. Obtaining cultural capital (Bourdieu, 1986), such as gaining U.S. citizenship and immediate acceptance to mainstream U.S. culture through marriage to a U.S. citizen, can make the entry into the school culture easier for internationally educated teachers than those teachers who do not have such advantages.

\subsection{Language Barriers}

Language barriers are often one of the most common and obvious challenges that internationally educated teachers encounter (Bascia, 1996; Flores, 2001; Myles, Cheng, \& Wang, 2006; Phillion, 2003). The challenges on the basis of language barrier can be attributed to the fact that the authoritative discourses (Bakhtin, 1998) recognize only American English as the acceptable language in the U.S. schools. Working in the U.S. school environment where the ability to speak like native English speakers is advantageous, the three internationally educated teachers experienced challenges due to their foreign accents. For example, Annabel, who had 5 years of English language instruction in her home country, struggled the most of the three participating teachers with her English: "Sometimes my students said that I talk[ed] funny."

Similarly, Mares mispronounced some English words (e.g., Mares pronounced New York as New Jork because the Spanish "y" pronounced like " $\mathrm{y}$ " in English), which, according to her observation, were often accurately interpreted by one of her students who always helped other students understand Mares each time she mispronounced a word: 
Vowels are very difficult for me to pronounce because .... [there are] short vowels and long vowels. And depending on what consonant goes before or after, it sounds one way or another way. Some of my students do not understand [me]...because I didn't use the correct pronunciation for that word with that vowel. But ...one of my students [is] on top of it. And he's helping ...the rest of the kids [to understand me]. And once [he] [did] that, they got it. [My pronunciation] is not going to be a problem at all.

Being an immigrant from Singapore, Niang has an Asian accent and speaks quickly. Occasionally, Niang's English was corrected by her students:

Sometimes I don't enunciate [words] correctly...Today one of the kids sa[id], "You said it wrong!" And then I said, "okay, how do you say it then?" So I learned [correct English] from the kids. Sometimes they correct my English when they hear my accent. But I don't take offense. I can learn from my students as they learn from me."

In a U.S. dominant school culture, teachers are expected to talk and sound like native English speakers. One of her students, who clearly has an assumption that there is only one acceptable language, American English, criticized Niang's English and corrected her pronunciation. According to Bakhtin's (1981) theory of language, the words come to us with the meaning and intentions of others and those intentions influence the listener. From the above excerpt, students believe that the language of the dominant culture is the norm, and that the teacher is expected to speak the language of dominant culture. This intention expressed through the words of her student influenced Niang to accept the authoritative discourse. Her reaction to her student showed that the student's English was the right one, and that it was acceptable to correct the English spoken by a teacher who is from outside U.S. mainstream culture. In other words, the intention of Niang's students, the dominant culture, was embedded in their words when they corrected Niang's English. Their beliefs, that the English of the authoritative discourses is the correct one, influenced Niang to accept such beliefs.

\section{Discussion}

This phenomenological study provided an insider perspective of the internationally educated teachers' shared experiences in terms of the challenges they faced in the U.S. public schools. This study attempted to expose the untold stories of internationally educated teachers and the challenges they faced as they adjusted to the U.S. public school system. As noted in the introduction, there is a lack of quantitative and qualitative research focusing on the personal stories that internationally educated teachers experience and how they manage to successfully overcome them (Bascia, 1996B; Cho, 2010; Oriaro, 2007; Phillion, 2003; Ragnarsdóttir, 2010; Smyth \& Kum, 2010; Zhang 2005; Subedi, 2008). It is in this spirit that this study explored the nature and reasons for the experienced challenges in terms of cultural differences and language barriers.

In this study, the internationally educated teachers were aware of the fact that they had to face persistent obstacles within the U.S. teaching environment. The degree to which they were able to overcome the obstacles determined the nature of the conflicts that they experienced. Failing to understand the school culture and follow its prescribed norms resulted in increased conflicts within the community and less acceptance by members of the dominant culture.

Interestingly, the entry to the mainstream culture seemed to be smoother when some of the internationally educated teachers gained cultural capital through their marriages to U.S. citizens. Whether the support was from a collaborating teacher who served as a role model or a spouse who was the U.S. citizen, the internationally educated teachers gained cultural capital from the support provided by members of the mainstream culture. Possessing cultural capital helped internationally educated teachers gain in-depth understanding of the host country more rapidly than their counterparts, and thus, provided them with better access to the mainstream culture. This has an implication for teacher education programs. Increased familiarity with the mainstream culture diminishes the challenges that internationally educated teachers face in their host country. Smyth and Kum (2010) emphasized the need for familiarization with the new context through "work shadowing and buddying systems" (p. 517). Having a partner from the mainstream culture that can serve as a role model or a mentor for internationally educated pre-service teachers will ease the transition into the mainstream culture.

This also has an implication for schools as well. It is important to provide internationally educated teachers with a mentor who is from the mainstream culture during the first year of teaching. However, whether it is a mentor for internationally educated teachers or a buddy for internationally educated pre-service teachers, it is important to point out that those mentors and buddies must have compassion and respect for internationally educated (pre-service) teachers. Mentoring should be based on a mutually respectful relationship. During the interview, Niang said the following: 
First of all, the [mentors] need to be willing to do it and open to teach, not like an expert, 'I'm going to tell you what to do'... I don't like that kind of attitude...Also, an effective teacher, somebody who probably has taught for at least five year[s]... And somebody who is open to new stuff. They are not closed minded, 'Oh, this is the way we have done it twenty years ago. So you are going to do it this way'. You know, that's not the way because things change and they need to be adaptable and flexible. And somebody who appreciates someone from another culture. It would be great if they traveled abroad and they are really interested in knowing people...I think those are the qualities [that mentors for internationally educated teachers] have to have [in order to have] a good working relationship...

As Niang pointed out, the qualities of mentors for internationally educated teachers/teacher candidates must possess a willingness to help, respect for internationally educated teachers as partners in education, multicultural experiences, open-mindedness, and appreciation for cultures outside their own.

The participants of this study struggled with classroom discipline which has been also observed by other researchers (e.g., Oriaro, 2007; Ross, 2003; Su, 1997). Oriaro, Ross, and Su found that many pre-service teachers and first-year teachers, especially from culturally and linguistically diverse backgrounds, struggled with classroom management. According to $\mathrm{Su}$, if internationally educated teachers continue to experience these conflicts without receiving any support, they may alienate themselves from the classroom and distance themselves from students. It is important for teacher education programs to increase instruction in how to manage student behavior for internationally educated pre-service teachers. Without this kind of training, many of these pre-service teachers will rely on their previous experience to fashion classroom management strategies which may not be effective in a U.S. classroom (Oriaro, 2007). It is important for teacher educators to understand the internationally educated pre-service teachers' previous student discipline practices and beliefs, and to find any discrepancy between their native country's educational practices and those of their host country in order to provide these pre-teachers with appropriate guidance.

As observed in this study this researcher also argued that the internationally educated teachers faced challenges because of the differences in the cultural experiences in their home countries and in the host country. The participants' statements showed how previous experiences in the home country shaped the actions and minds of individuals in order to interpret their current situations as cultural outsiders in a host country. In most cases, their previous experiences were deemed as less valuable than the experiences gained from mainstream culture of the host country. This is an example of institutional discrimination, which is defined as institutional procedures and practices which work against the interests of certain groups even though there may be no conscious decision to discriminate. It is important for school administrators to provide internationally educated teachers with welcoming environment where they can share their multicultural experiences with other colleagues. According to Ragnarsdóttir (2010), school administrators should create school environment that respects and cultivates diversity and equity at school. It is important that in globalized societies, schools acknowledge and promote diversity among their teaching staff. School administrators and teachers from mainstream culture need to provide a supportive and encouraging environment for those who are hired from under-represented communities for effective participation and success in the teaching profession. (Schmidt, 2010)

Although several studies have been conducted regarding students from diverse cultural and linguistic backgrounds, the number of research studies about internationally educated teachers is relatively small. This has an implication for teacher education. As Schmidt (2010) suggested, teacher educators should conduct participatory action research in communities of internationally educated teachers in order to understand the challenges these teachers face when they enter the teaching profession in the United States.

All three internationally educated teachers experienced prejudice against them due to their foreign-accented English. It is important for internationally educated teachers to expose U.S. mainstream students about the different pronunciations and accents of English spoken outside the United States. In $21^{\text {st }}$ century, people from all over the world use English as a means to communicate with each other, thus, speak English with various accents that reflect their mother tongues. Naturally students in a global world are expected to respect and understand various English accents and pronunciations from outside the United States. It would be disrespectful for native English speakers to correct other people for their foreign accent in any forum. In this respect, internationally educated teachers can better prepare U.S. native English speaking students for globalization by exposing them to various versions of English. It is imperative that internationally educated teachers realize the power of their contribution for students in U.S. schools with this kind of global education.

Cultural discrimination is observed where there are collective assumptions about normality and unquestioned ideas (Smyth \& Kum, 2010). Annabel critically pointed out the shared assumption that only the accents spoken 
by people from outside ethnic majority are questioned, and that those accents are viewed in deficit perspective. Cook (1999) challenged such authoritative discourses and illuminated the multicompetent qualities of the second language learners in terms of linguistic and cultural knowledge. He argued that second language learners are "not failed or deficient native speakers, but are multicompetent speakers who potentially possess more linguistic and cognitive abilities than a mere native speaker" (p. 190). Besides speaking more than one language means owning the knowledge of more than one social and cultural belief. In this respect, internationally educated teachers should be viewed as proficient and multicompetent, not as deficient.

In conclusion, the researcher argues that, while stories of the three internationally educated teachers do not represent every internationally educated teacher in U.S. public schools, their accounts offer insights for examining the challenges that internationally educated teachers encounter. Specifically, classroom discipline, conflicts with parents, and language barriers were the common challenges faced by each of the three internationally educated teachers interviewed.

\section{References}

Abramova, I. (2012). Perspectives of Teachers from the Soviet Union in U.S. Schools: Through the Eyes of Immigrant Teachers Who "Tend to Go against the Grain". Multicultural Education, 19(3), 34-38.

Apostol, J. (2008). A study of factors related to job selection for minority teachers (Unpublished doctoral dissertation). Saint Louis University, Saint Louis, U.S.A.

Aronson, P., \& Geroge, P. (2003). How do educators' cultural belief systems affect underserved students' pursuit of postsecondary education? Briefing Papers. Pacific resources for education and learning (PRESL): Hawaii. Retrieved from http://www.prel.org/products/pn_/cultural-belief.htm

Bakhtin, M. (1998). Discourse in the Novel: The Topic of the Speaking Person. In Ed. David, \& H. Richter (Eds.) The Critical Tradition: Classic Texts and Contemporary Trends (pp. 527-539). Boston: Bedford/St. Martin's.

Bascia, N. (1996). Inside and outside: Minority immigrant teachers in Canadian schools. Qualitative Studies in Education, 9(2), 151-165. http://dx.doi.org/10.1080/0951839960090204

Beyon, J., Ilieva, R., \& Dichupa, M. (2004). Re-credentialing experiences of immigrant teachers: Negotiating institutional structures, professional identities and pedagogy. Teachers and Teaching: Theory and Practice, 10(4), 429-444. http://dx.doi.org/10.1080/1354060042000224160

Bourdieu, P. (1986). The Forms of Capital. In J. G. Richardson, \& P. Bourdieu (Eds.), Handbook of Theory and Research for the Sociology of Education. New York: Greenwood Press.

Cho, C. L. (2010). "Qualifying” as teacher: immigrant teacher candidates' counter-stories. Canadian Journal of Educational Administration and Policy, 100.

Clewell, B. C., \& Villegas, A. M. (2001). Evaluating the Pathways to Teaching Careersprogram. Absence unexcused: Ending teacher shortages in high-need areas. Washington, DC: The Urban Institute.

Cook, V. (1999). Going beyond the native speaker in language teaching. TESOL Quarterly, 33(2), 185-209. http://dx.doi.org/10.2307/3587717

Dahlberg, K., Dahlberg, H., \& Nystrom, M. (2008). Reflective life world research. Studentlitteratur: Lund, Sweden.

Department of Education and Science. (1985). Education for all: Final report of the committee of inquiry into the education of children from ethnic minority groups. London: HMSO.

Evans, C. A., Arnot-Hopffer, E., \& Jurich, D. (2005). Making Ends Meet: Bringing Bilingual Education and Mainstream Education Students Together in Preservice Teacher Education. Journal of Equity and Excellence in Education, 38(1), 75-88. http://dx.doi.org/10.1080/10665680590907855

Flores, B. B. (2001). Thinking out of the box: One university's experience with foreign-trained teachers. Educational Policy Analysis Archives, 9(18).

Francis, T. A. (2005). Cross-cultural perspectives of migrant Jamaican teachers in New York City (Unpublished doctoral dissertation). Colombia University, New York, U.S.A.

Goodson, I., \& Cole, A. (1993). Exploring the Teacher's Professional Knowledge. In D. McLaughlin, \& W. Tierny (Eds.), Naming Silenced Lives: Personal Narratives and the Process of Educational Change (pp. 71-94). New York, NY: Routledge. 
Gordon, E. W. (2000). Production of knowledge and pursuit of understanding. In C. Yeakey (Ed.), Producing Knowledge, Pursuing Understanding. Stanford, CT: Jai Press. $\mathrm{http}: / / \mathrm{dx}$. doi.org/10.1016/S1479-358X(00)80025-X

Griffiths, J., \& Hope, T. (2000). Access to Sociology: Stratification and differentiation. London: Hodder and Stoughton.

Hodge, K. (2005). (Re)writing the script: How immigrant teachers (re)constructidentity in a Canadian private language school setting (Unpublished master's thesis). University of Simon Fraser, Canada.

Hwang, Y. S., Baek, E. O., \& Vrongistinos, K. (2005). Immigrant Hispanic/Latinos teachers' perception of education. Paper presented at the meeting of the American Educational Research Association.

Irvine, J. J. (1990). Black students and school failure: Policies, practices, and prescriptions. New York: Greenwood Press.

Kamler, B., Reid, J., \& Santoro, N. (1999). Who's asking the questions? Researching race, ethnicity and teachers. Australian Education Researcher, 26(1), 55-74. http://dx.doi.org/10.1007/BF03219688

Kauchak, D., \& Burbank, M. D. (2003). Voices in the Classroom: Case Studies of Minority Teacher Candidates. Action in Teacher Education, 19(5), 499-514.

Ladson-Billings, G. (1995). Just what is critical race theory and what's it doing in a nice field like education? Qualitative Studies in Education, 11(1), 7-24. http://dx.doi.org/10.1080/095183998236863

Ladson-Billings, G. (2001). Crossing over to Canaan. The journey of new teachers in diverse classrooms. San Franciso: Jossey-Bass.

Lumby, J., \& Coleman, M. (2007). Leadership and diversity. Challenging theory andpractice in education. Los Angeles: Sage.

Madsen, J. A., \& Mabokela, R. O. (2000). Organizational Culture and Its Impact on African American Teachers. American Educational Research Journal, 24(2), 849-876. http://dx.doi.org/10.3102/00028312037004849

Maguire, M. J. (1997). The School Experience of Some Minority Ethnic Students inLondon Schools during Initial Teacher Training. Journal of Education for Teaching: International research and pedagogy, 23(2), 131-144.

Mawhinney, H., \& Xu, F. (1997). Reconstructing the Professional Identity of Foreign-Trained Teachers in Ontario Schools. Language and Identity. TESOL Quarterly, 31(3), 632-639. http://dx.doi.org/10.2307/3587847

Milner, H. R. (2003). Teacher reflection and race in cultural contexts: History, meanings, and methods in teaching. Theory into practice, 42(3), 171-179. http://dx.doi.org/10.1207/s15430421tip4203_2

Myles, J., Cheng, L., \& Wang, H. (2006). Teaching in elementary school: Perceptions of foreign-trained teacher candidates on their teaching practicum. Teaching and Teacher education, 22, 233-245. http://dx.doi.org/10.1016/j.tate.2005.09.001

National Clearinghouse for English Language Acquisition. (2011). The growing numbers of English learner Students 2009/10. Retrieved from http://www.ncela.gwu.edu/files/uploads/9/growing_EL_0910.pdf

Nieto, S. (1999). The Light in their Eyes: Creating Multicultural Learning Communities. New York: Teachers College Press.

Oloo, J. A. (2012). Immigrant teachers in Saskatchewan: A human resource perspective. KEDI Journal of Education Policy, 9(2), 219-237.

Omi, M., \& Winant, H. (1994). Racial formations in the United States. New York, NY: Routledge.

Ontario College of Teachers. (2008). Transition to teaching. Retrieved from http://www.oct.ca

Oriaro, I. K. (2007). Initial classroom discipline issues encountered by Kenyanimmigrant teachers in Southern California (Unpublished doctoral dissertation). Biola University, California, U.S.A.

Osler, A. (1997). The Education and Careers of Black Teachers. Buckingham: Open University Press.

Ozbarlas, Y. (2008). Perspectives on multicultural education: Case studies of a German and an American female minority teacher (Unpublished doctoral dissertation). Georgia State University, Georgia, U.S.A.

Peeler, E., \& Jane, B. (2005). Mentoring: Immigrant teachers bridging professional practices. Teaching Education, 16(4), 325-336. http://dx.doi.org/10.1080/10476210500345623 
Phillion, J. (2003). Obstacles to accessing the teaching profession for immigrantwomen. Multicultural Education, $11(1), 41-45$.

Pollock, K. (2006). Internationally trained teachers. University of Toronto. Retrieved from http://www.wallnetwork.ca/resources/Pollock_Internationally_Trained_Teachers_WALL200.pdf

Quiocho, A., \& Rios, F. (2000). The power of their presence: Minority group teachers and schooling. Review of Educational Research, 70(4), 485-528. http://dx.doi.org/10.3102/00346543070004485

Ragnarsdóttir, H. (2010). Internationally educated teachers and student teachers in Iceland: Two qualitative studies. Canadian Journal of Educational Administration and Policy, 100.

Redmond, C., Clinedinst, M., \& O'Brien, C. (2000). Educating the Emerging Majority: The Role of Minority-Serving Colleges \& Universities in Confronting America's Teacher Crisis. A Report from the Alliance for Equity in Higher Education. Institute for Higher Education Policy, Washington, DC.

Ross, F. (2003). Newcomers entering teaching: A program created for recent immigrants and refugees to become certified teachers. Paper presented at the American Educational Research Association, Chicago, IL.

Rushton, J. P. (2000). Race, evolution, and behavior: A life history perspective (3rd ed.). Port Huron, MI: Charles Darwin Research Institute.

Ryan, J., Pollock, K., \& Antonelli, F. (2009). Teacher diversity in Canada: Leaky Pipelines, Bottlenecks and Glass Ceilings. Canadian Journal of Education, 32(3), 512-538.

Santoro, N. (2008). 'Outsiders' and 'others': 'Different' teachers teaching in culturally diverse classrooms. Teachers and Teaching, 13, 81-97. http://dx.doi.org/10.1080/13540600601106104

Schmidt, C. (2010). Systemic discrimination as a barrier for immigrant teachers. Diaspora, Indigenous, and Minority Education (DIME). http://dx.doi.org/10.1080/15595692.2010.513246

Sethi, R. (1998). Smells like racism. In P. S. Rothenberg (Ed.), Race, class and gender in the United States: An Integrated Study (pp. 154-164). New York: St. Martin's

Siraj-Blatchford, I. (1994). The Early Years: Laying the Foundations for Racial Equality. Stoke-on-Trent, Trentham.

Skutnabb-Kangas, T. (1998). Multilingualism and the education of minority children. In T. S. Kangas, \& J. Cummins (Eds.), Minority education: From shame to struggle (pp. 9-44). Clevedon, UK: Multilingual Matters.

Smyth, G., \& Kum, H. (2010). 'When they don't use it they will lose it': Professionals, deprofessioanlization and reprofessionalization: The case of refugee teachers in Scotland. Journal of Refugee Studies, 23(4), 503-523. http://dx.doi.org/10.1093/jrs/feq041

$\mathrm{Su}, \mathrm{Z}$. (1997). Teaching as a profession and a career: Minority candidates' perspectives. Teaching and Teacher Education, 13, 325-340. http://dx.doi.org/10.1016/S0742-051X(96)00021-2

Subedi, B. (2008). Contesting racialization: Asian immigrant teachers' critiques and claims of teacher authenticity. Race Ethnicity and Education, 11(1), 57-70. http://dx.doi.org/10.1080/13613320701845814

Vagle, M. D. (2009). Validity as intended: 'bursting forth toward' bridling in phenomenological research. International Journal of Qualitative Studies in Education, 22(5), 585-605. http://dx.doi.org/10.1080/09518390903048784

Vagle, M., Hughes, H., \& Durbin, D. (2009). Remaining skeptical: Bridling for and with one another. Field Methods, 1-21. http://dx.doi.org/10.1177/1525822X09333508

Van Manen, M. (1990). Researching lived experience: Human science for an action sensitive pedagogy. Althouse Press: London: Ontario, Canada.

Wang, C. (2002). Innovative teaching in EFL contexts: The case of Taiwan. In S. J. Savignon (Ed.), Communicative Language Teaching in Translation: Contexts and Concerns in Teacher Education (pp. 131-153). New Haven: Yale University Press.

Webster, N., \& Valeo, A. (2011). Teacher preparedness for a changing demographic of language learners. TESL Canada journal, 28(2), 105-128.

Yee, R. (2008). An exploratory study of the perceived internal and external barriersthat Cambodian American teachers face as they pursue their teaching position in selected Los Angeles County Districts and the 
strategies they used to overcome these barriers (Unpublished doctoral dissertation). University of La Verne, California, U.S.A.

Yosso, T. J. (2005). Whose culture has capital? A critical race theory discussion of community cultural wealth. Race Ethnicity and Education, 8(1), 69-91. http://dx.doi.org/10.1080/1361332052000341006

Zhang, L. (2006). The experiences of foreign-trained immigrant teachers in their teaching practica in Ontario elementary schools (Doctoral dissertation). Available from World Cat Dissertations (ISBN: 9780494132425 0494132426).

\section{Copyrights}

Copyright for this article is retained by the author(s), with first publication rights granted to the journal.

This is an open-access article distributed under the terms and conditions of the Creative Commons Attribution license (http://creativecommons.org/licenses/by/3.0/). 